\title{
Case of giant left atrium from congestive heart failure
}

\author{
Michael Z Grzeskowiak, Navid Ahmed
}

Department of Medicine, Albert Einstein College of Medicine, Bronx, New York, USA

\section{Correspondence to} Dr Navid Ahmed, nahmed@montefiore.org

Accepted 16 June 2018

\section{DESCRIPTION}

A 79-year-old woman with a history of diastolic heart failure, pulmonary hypertension and rheumatic heart disease status-post mitral valve replacement presented with worsening shortness of breath and exercise tolerance for 1 month. Her exercise tolerance had decreased from 5 city blocks to several feet, while her weight had increased from 174 pounds to 187 pounds. On examination, she was unable to lay flat, her jugular venous pressure was $15 \mathrm{~cm}, \mathrm{C}$ and $\mathrm{V}$ waves were positive, she had a mechanical S1, 4/6 holosystolic murmur, $1 / 4$ diastolic murmur, displaced point of maximal impulse, right ventricular heave, a pulsatile liver and $2+$ pitting oedema in her lower extremities. Echocardiogram revealed an ejection fraction $55 \%, \mathrm{E} / \mathrm{E}^{\prime}$ 21 and a left atrial diameter of $11 \mathrm{~cm}$ (figure 1). A prior CT scan of her chest showed massive cardiomegaly with collapse of the right lower and right middle lobe due to compression from the heart (figure 2). It also demonstrated rheumatic calcifications of the posterior left atrium.

During her hospital course, she developed acute hypoxic respiratory failure and required intubation. She was diuresed with high dose intravenous furosemide with symptom improvement and extubated on hospital day 3.

Our patient presented with classic symptoms of heart failure and was noted to have biatrial enlargement with a measurement of $11 \mathrm{~cm}$ in diameter of the left atrium. Giant left atrium (GLA), defined as a left atrium larger than $8 \mathrm{~cm}$, is a rare condition that has a reported incidence of $0.3 \% .^{1}$ The aetiology of GLA is usually rheumatic heart disease, which is a rare occurrence in the USA with a reported

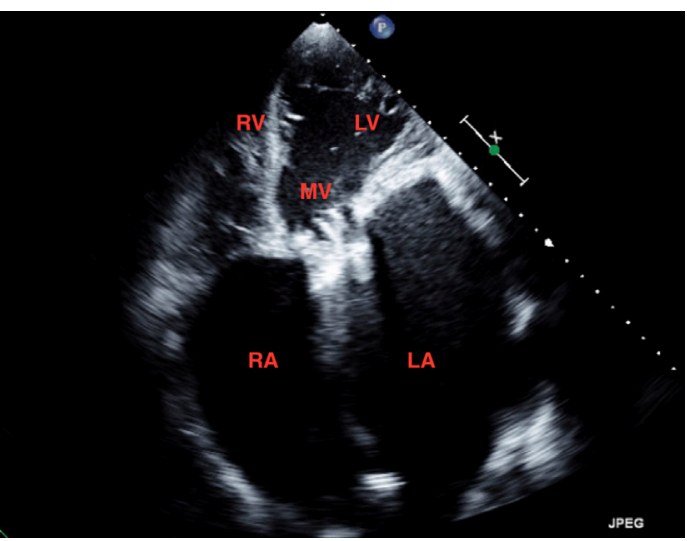

Figure 1 A four-chamber view on a transthoracic echocardiogram demonstrating biatrial enlargement.

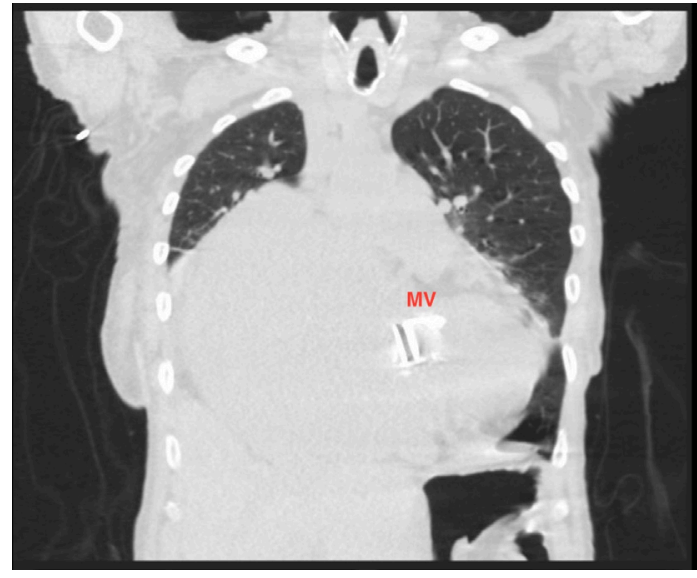

Figure 2 A coronal view of a CT chest demonstrating massive cardiomegaly with collapse of the right lower and right middle lobe. .

incidence of 0.3 per 1000 persons. ${ }^{2}$ Patients with GLA almost always have concomitant severe mitral regurgitation, atrial fibrillation and dysphagia. ${ }^{3}$

\section{Learning points}

- Giant left atrium (GLA) is defined as a left atrium larger than $8 \mathrm{~cm}$ and has a reported incidence of $0.3 \%$.

- The most common aetiology of GLA is rheumatic heart disease.

Contributors MZG collected the images for the case and the compisiton of the text of the case. NA assisted in writing the body of the case and with revisions. NA and MZG were involved in the clinical care of the patient.

Funding The authors have not declared a specific grant for this research from any funding agency in the public, commercial or not-for-profit sectors.

Competing interests None declared.

Patient consent Next of kin consent obtained.

Provenance and peer review Not commissioned; externally peer reviewed.

(c) BMJ Publishing Group Ltd (unless otherwise stated in the text of the article) 2018. All rights reserved. No commercial use is permitted unless otherwise expressly granted.

\section{REFERENCES}

1 El Maghraby A, Hajar R. Giant left atrium: a review. Heart Views 2012;13:46-52.

2 World Health Organization. Rheumatic fever and rheumatic heart disease. World Health Organ Tech Rep Service 2004;923:1-122.

3 Ates M, Sensoz Y, Abay G, et al. Giant left atrium with rheumatic mitral stenosis. Tex Heart Inst J 2006;33:389-91. 
Copyright 2018 BMJ Publishing Group. All rights reserved. For permission to reuse any of this content visit http://group.bmj.com/group/rights-licensing/permissions.

BMJ Case Report Fellows may re-use this article for personal use and teaching without any further permission.

Become a Fellow of BMJ Case Reports today and you can:

- Submit as many cases as you like

- Enjoy fast sympathetic peer review and rapid publication of accepted articles

Access all the published articles

- Re-use any of the published material for personal use and teaching without further permission

For information on Institutional Fellowships contact consortiasales@bmjgroup.com

Visit casereports.bmj.com for more articles like this and to become a Fellow 